\title{
Catalytic Activity of a Bifunctional Catalyst for Hydrotreatment of Jatropha curcas L. Seed Oil
}

\author{
J. García-Dávila $\mathbb{D}^{1,2}$ E. Ocaranza-Sanchez, ${ }^{1}$ C. Sánchez, ${ }^{3}$ and A. L. Martínez-Ayala $\mathbb{D}^{4}$ \\ ${ }^{1}$ Instituto Politécnico Nacional, Centro de Investigación en Biotecnología Aplicada, 90700 Tepetitla de Lardizabal, Tlaxcala, Mexico \\ ${ }^{2}$ Universidad Politécnica de Tlaxcala, Av. Universidad Politécnica No. 1, San Pedro Xalcaltzinco, 90180 Tepeyanco, Tlaxcala, Mexico \\ ${ }^{3}$ Universidad Autónoma de Tlaxcala, Laboratorio de Biotecnología, Centro de Investigación en Ciencias Biológicas, \\ 90120 Tlaxcala, Mexico \\ ${ }^{4}$ Instituto Politécnico Nacional, Centro de Desarrollo de Productos Bióticos, 62731 Yautepec Morelos, Mexico
}

Correspondence should be addressed to J. García-Dávila; jorge.garcia@uptlax.edu.mx and A. L. Martínez-Ayala; alayala@ipn.mx

Received 12 October 2017; Accepted 6 February 2018; Published 23 April 2018

Academic Editor: Binoy K. Saikia

Copyright (C) 2018 J. García-Dávila et al. This is an open access article distributed under the Creative Commons Attribution License, which permits unrestricted use, distribution, and reproduction in any medium, provided the original work is properly cited.

\begin{abstract}
The hydrotreating process of vegetable oils (HPVO) involves the transformation of vegetable oil triglycerides into straight chain alkanes, which are carried out by deoxygenation reactions, generating multiple hydrocarbon compounds, cuts similar to heavy vacuum oil. The HPVO is applied to Jatropha curcas oil on USY zeolite supported with gamma alumina and platinum deposition on the catalytic as hydrogenation component. The acid of additional activity of the supports allows the development of catalytic routes that the intervention of catalytic centers of different nature reaches the desired product. The products of the hydrotreating reaction with Jatropha curcas seed oil triglycerides were identified by Fourier transform infrared spectroscopy and by mass spectroscopy to identify and analyze the generated intermediate and final hydrocarbon compounds.
\end{abstract}

\section{Introduction}

Currently, there is a decline in fossil fuel reserves by contrast, every year the increase in demand for liquid fuels, such as environmental pollution due to excessive use; it is necessary to obtain renewable liquid fuels from natural sources. Triglyceride-based vegetable oils are a potential raw material for the production of biofuels. Jatropha curcas seed oil is one of the most important alternative nonedible types of vegetable oils for biofuel production [1]. The fluid catalytic cracking (FCC) process uses fossil fuels to produce, that is, gasoline, diesel, and olefins, where large molecules are broken down with the help of a catalyst [2].

Catalyst is the key factor in promoting high activity and selectivity to product distribution. In fact, new research materials focus on improving catalytic activity and generate fewer by-products and contaminants [3]. The heterogeneous catalyst is the great economic impact as the USY zeolite which provides high activity and selectivity of the catalysts.
USY is a large pore crystalline material having a maximum aperture of $0.74 \mathrm{~nm}$, a cell unit size of about $2.45 \mathrm{~mm}$, a $\mathrm{Si} / \mathrm{Al}$ ratio of 3 to 5 , and having shape selectivity to have the sites more active in the microporous structure [4].

The zeolite USY is widely used as a catalyst support and plays an important role in the catalysts used in the hydrocracking process because they enhance catalytic activity, selectivity, or stability imparting shape selectivity [5]. However, the high acidity of the zeolite carrier increases undesirable cracking activity, which accelerates the rate of coke deposition. The incorporation of a metallic phase on the support materials with a high dispersion allows the development of catalytic routes in which the intervention of catalytic centers of different nature achieves the desired product [6] (multifunctional catalysts).

Conventional hydrotreating involves the removal of heteroatoms, such as sulfur and nitrogen. The hydrocracking process involves the saturation and breakage of $\mathrm{C}-\mathrm{C}$ bonds to produce high-grade gasoline and diesel fuels [7]. A novel 
alternative for the production of biofuels is catalytic hydrotreatment and hydrocracking of vegetable oils [8].

Hydrotreatment of vegetable oil and its mixtures with heavy vacuum gas oil has been explored to produce biofuels using conventional hydrotreating catalysts based on Ni-Mo/ $\mathrm{Al}_{2} \mathrm{O}_{3}$ and $\mathrm{Co}-\mathrm{Mo} / \mathrm{Al}_{2} \mathrm{O}_{3}$ [9] under conventional conditions of nominal hydrodesulfurization operation [10]. A novel alternative to manufacture biofuels is catalytic hydrotreatment and hydrocracking of vegetable oils. Several hydrotreated vegetable oils include palm oil [11], Jatropha curcas L. [12], Jatropha cinerea oil [13], and soybean lecithin [14].

USY zeolite has been reported to use as a catalyst for cracking of waste cooking oils [15] and Jatropha curcas [16]. Favor you apply in very different pressure and temperature conditions. In this work, we use the $\gamma$-alumina which is the most commonly used as support on which the active component in this case is dispersed the zeolite USY which presents activity acid. In addition, in the form of dispersion are incorporated platinum particles that act as a function of hydrogenation in the catalyst for the hydrotreatment of Jatropha curcas seed oil [17].

\section{Experimental}

2.1. Jatropha curcas Seed Oil. The Jatropha curcas L. seed species used in this study are native to the state of Puebla, Mexico. The seed oil was extracted by mechanical pressing using an ELVEC press. The vegetable oil was used without a pretreatment.

2.2. Preparation of Zeolite USY. The support used was $\gamma$-alumina with a specific surface area of $270 \mathrm{~m}^{2} / \mathrm{g}$ and a volume of $0.8 \mathrm{~cm}^{3} / \mathrm{g}$. It was mixed with zeolite USY at 10 and $20 \mathrm{wt} \%$. The samples were extruded and dried at $110^{\circ} \mathrm{C}$ overnight and calcined in air at $500^{\circ} \mathrm{C}$ for $4 \mathrm{~h}$. This mixture was used as platinum metal support. The catalysts were prepared by impregnating the aqueous solution of chloroplatinic acid $\left(\mathrm{H}_{2} \mathrm{PtCl}_{6}\right)$ as a precursor using the incipient impregnation wetness method. After impregnation, the sample was dried at $110^{\circ} \mathrm{C}$ overnight, followed by calcination at $500^{\circ} \mathrm{C}$ for $4 \mathrm{~h}$ in a muffle furnace. After activation, the catalyst was reduced for $4 \mathrm{~h}$ at $400 \mathrm{psia}$ and $400^{\circ} \mathrm{C}$ under a hydrogen flow of $60 \mathrm{~mL} \mathrm{~min}^{-1}$.

The adsorption of water was used as a manual method for the determination of the specific surface [18]; it is a simple and economical approximation to obtain the value of $0.45 \mathrm{~mL} / \mathrm{g}$ of catalyst $( \pm 0.01)$. Both the pore volume and the pore size of the zeolite are smaller than the alumina sample. The presence of Pt partially reduces the sites, responsible for coking [19] for their masking with the metal particles Pt; hence, the activity of the catalyst persists over a long period.

2.3. Catalytic Activity. The catalytic performance of the bifunctional catalyst was investigated by hydrotreating Jatropha curcas seed oil in a continuous flow tubular reactor of $9 \mathrm{~mm}$ internal diameter and $300 \mathrm{~mm}$ in length vertically within the tubular programmable temperature. Nitrogen gas was introduced into the system to fully purge air from the system while the reactor reached the desired temperature. The hydrotreating process was carried out under the following conditions: temperature 310,360 , and $390^{\circ} \mathrm{C}$, total pressure $400 \mathrm{psi}$, hourly space velocity by weight (WHSV) $176.4-35.28 \mathrm{~h}^{-1}$ ( 0.5 and $0.1 \mathrm{~g}$ of the catalyst were charged), and hydrogen to feed oil molar ratio of 15 .

2.4. Analysis of Hydrotreatment Samples. The analysis of the products was performed using a Fourier transform infrared spectroscopy (FTIR). Using a Bruker Vertex-70 unit in an ATR (attenuated total reflectance) sampling mode, the system is equipped with an OPUS program for data acquisition and the region of measurement was the middle infrared (4000-400 $\mathrm{cm}^{-1}$ ) with a resolution of $4 \mathrm{~cm}^{-1}$. Subsequently, the liquid products were analyzed using an Agilent 7890A GC/MSD gas chromatograph, with the G4513A auto sampler coupled to a 5975C VL MSD mass spectrometer with triple axis detector; a capillary HP-5MS $\left(30 \mathrm{~m}^{*} 320 \mu \mathrm{m}^{*} 0.25 \mu \mathrm{m}\right)$ was used with the external standard technique for quantification. The GC/MSD parameters were oven program, $70^{\circ} \mathrm{C}$ for $5 \mathrm{~min}, 20^{\circ} \mathrm{C} / \mathrm{min}$ at $200^{\circ} \mathrm{C}$ for $5 \mathrm{~min}$, and then $10^{\circ} \mathrm{C} / \mathrm{min}$ at $300^{\circ} \mathrm{C}$ for $5 \mathrm{~min}$, with an injection volume of $2 \mu \mathrm{L}$ and temperatures of $230^{\circ} \mathrm{C}$ and $150^{\circ} \mathrm{C}$ for MS source and quadruple, respectively, with the ChemStation program for data acquisition in mode scan.

A calibration curve was taking from the previous work of García-Dávila et al. [20] that represents the band intensity quantification at $1743 \mathrm{~cm}^{-1}$ and $1160 \mathrm{~cm}^{-1}$, indicating the abundance of fatty acids (Figures 1 and 2). Using Jatropha curcas seed oil spectrum as the maximum content of oxygenates compounds, and n-hexadecane as hydrocarbon molecule model as the minimum oxygenated compounds, this compound was taken an internal standard to represent the final hydrotreatment product. The reduction of the signal in the band intensity at $1743 \mathrm{~cm}^{-1}$ and $1160 \mathrm{~cm}^{-1}$ was quantified and correlated with the conversion [21].

\section{Results}

3.1. Spectrometry FTIR. The hydrotreatment tests were performed by testing the $\mathrm{Al}_{2} \mathrm{O}_{3}$ support loaded with two percentages of 10 and 20\% USY zeolite to observe the effect of the acid activity of the zeolite on the oil. Subsequent to the appropriate relationship, platinum $(\mathrm{Pt})$ molecules are incorporated by the incipient wetness impregnation method to add the hydrogenating function; two different weight fractions as indicated in Table 1 were tested to quantify the specific metallic activity in the catalyst.

A comparison of hydrotreated samples was carried out by attenuated total reflectance spectroscopy (FTIR-ATR), where the amplitude of the oil peaks was compared with the amplitude of the peaks of the hydrotreated samples. It was taken as the baseline below the n-hexadecane spectrum $(100 \%$ conversion) and Jatropha curcas oil as the upper base ( $0 \%$ conversion) to standardize the magnitudes of the FTIR peaks and quantitatively establish the conversion, a calibration curve by means of dilutions of the oil with hexadecane (Figures 1 and 2). From the correlation of the signal intensity of the spectra by the FTIR of the samples, the limit of the 


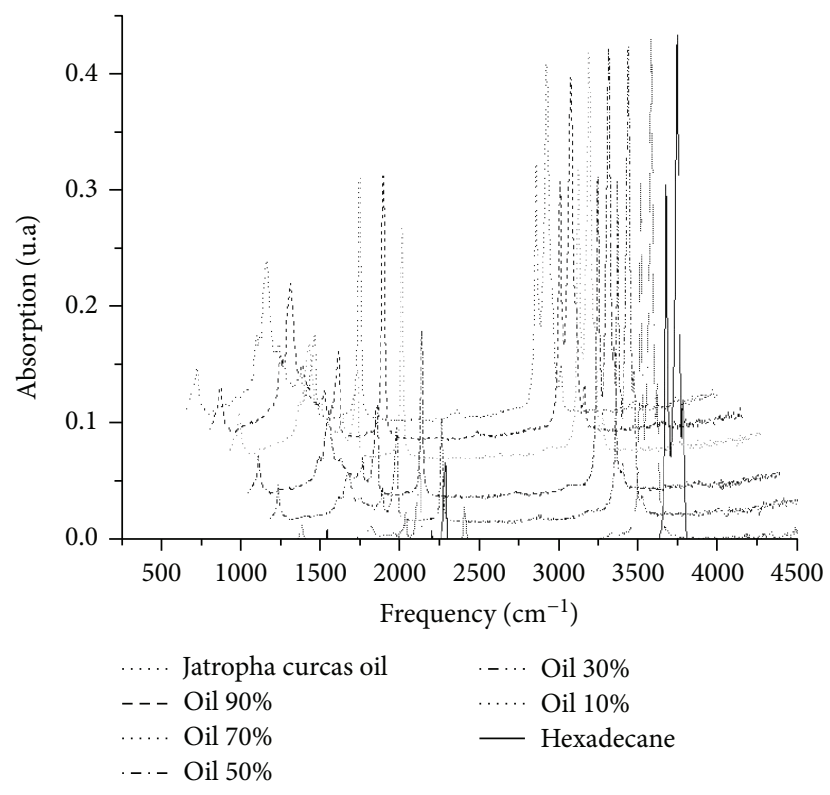

FIGURE 1: FTIR spectra of calibration curve of Jatropha curcas oil with hexadecane [12].
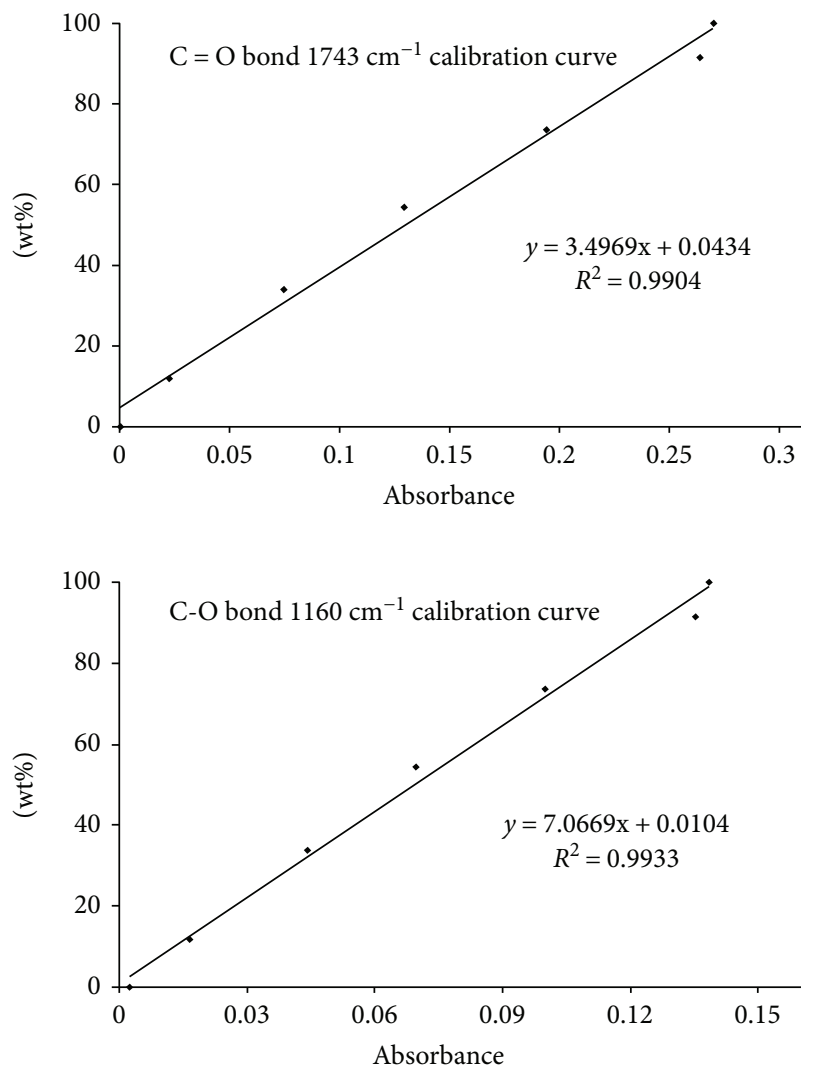

Figure 2: Calibration curve of Jatropha curcas seed oil dilutions with hexadecane at 1743 and $1160 \mathrm{~cm}^{-1}$ wavelength [12].

superior of the respect and the inferior one determined the progress in the reduction of the band intensity of the fatty acids in a process of hydrotreatment of Jatropha curcas seed oil.
TABLE 1: Formulation of bifunctional catalyst for hydrotreatment of Jatropha curcas seed oil.

\begin{tabular}{lcc}
\hline $\begin{array}{l}\text { Quantity of USY zeolite } \\
\text { on gamma alumina }\end{array}$ & $\begin{array}{l}\text { Catalyst charging } \\
\text { to the reactor }(\mathrm{g})\end{array}$ & Platinum (\%) \\
\hline & 0.5 & 0.05 \\
$0 \% \mathrm{USY} / \mathrm{Al}_{2} \mathrm{O}_{3}$ & & 0.01 \\
$10 \% \mathrm{USY} / \mathrm{Al}_{2} \mathrm{O}_{3}$ & 0.1 & 0.05 \\
$20 \% \mathrm{USY} / \mathrm{Al}_{2} \mathrm{O}_{3}$ & & 0.01 \\
\hline
\end{tabular}

There was a decrease in the characteristic peaks of the fatty acids in the hydrotreatment samples; this phenomenon was registered at temperatures of $310^{\circ} \mathrm{C}$ according to the increase of the operating temperature. To discriminate the thermal cracking effect on the hydrotreatment process, a test without catalyst was run, where the evidence shows that there is no significant difference between the FTIR spectra with respect to the crude oil which demonstrates that there is no thermal degradation of the triglyceride and the process only develops as a function of the bifunctional catalyst (Figure 3). These data are consistent with those reported by Idem et al. [22] for canola oil, wherein the thermal cracking is significant above $400^{\circ} \mathrm{C}$ and increases with operating temperature.

It is observed that at higher USY zeolite/alumina ratio, there is a higher acid activity like sulfur-type catalysts such as Co-Mo and $\mathrm{Ni}-\mathrm{Mo}$, with conversions above $60 \%$ at residence times, like those reported for other catalysts [23].

From the analysis by FTIR, a shift to low frequencies in the wave number is observed by the presence of characteristic peaks of carbonyl and carboxyl groups. These representing the formation of compounds with functional groups of ketones and aldehydes which are considered as the first intermediate products generated in the hydrotreatment process [24] after the disintegration of the triglyceride, this information will be corroborated by gas chromatography coupled to mass spectroscopy.

The absorption band shift was recorded with a wavelength of 1743 to $1710 \mathrm{~cm}^{-1}$ corresponding to group $(\mathrm{C}=\mathrm{O})$ characteristic of ketones and aliphatic aldehydes Figure 4 unlike the group $(\mathrm{C}=\mathrm{O})$ of the fatty acids that has a lower stability because of not containing the $(\mathrm{OH})$ group. The signal from this group increases its absorbance by increasing the operating temperature of the hydrotreatment process, which indicates that more fatty acid reduction is present at higher operating temperatures [25].

With the formulation of the $20 \%$ USY $/ \mathrm{Al}_{2} \mathrm{O}_{3}$ catalyst, platinum particles were incorporated by the incipient wetness impregnation method. To this end, a solution of chloroplatinic acid $\mathrm{H}_{2} \mathrm{PtCl}_{6}$ was prepared from the grams of platinum to be incorporated into the matrix of $0.01,0.05$, and $0.1 \mathrm{~g}$, respectively, with a comparison being made between the catalytic activities for each formulation of the bifunctional catalyst.

The results show that the catalyst with the highest activity to hydrocarbon transformation is the formulation with $20 \%$ of zeolite USY $/ \mathrm{Al}_{2} \mathrm{O}_{3}$ with a percentage of $0.01 \% \mathrm{Pt}$ (Figure 5). Since at higher percentages, the metallic phase 


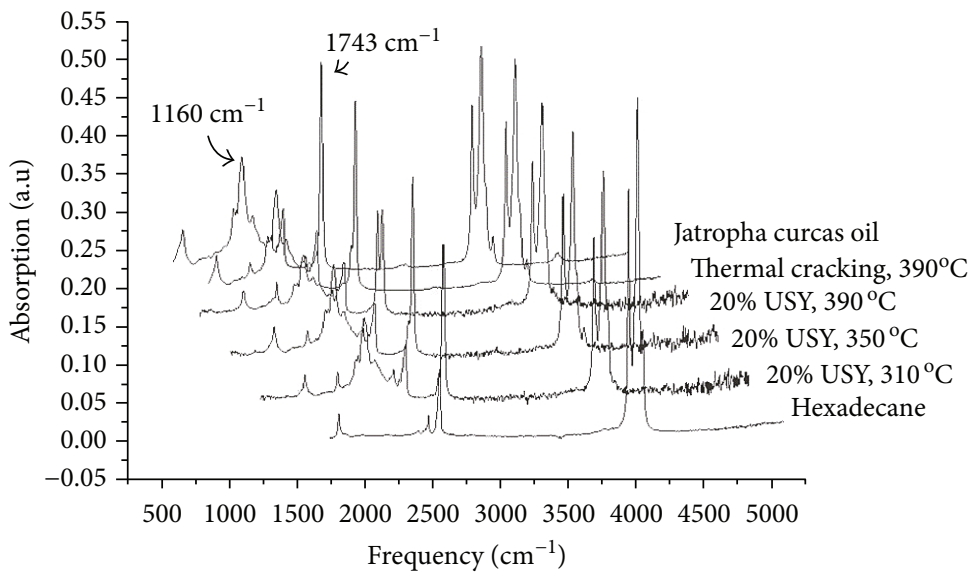

FIGURE 3: FTIR spectra of hydrotreated oil at different temperatures with WHSV of $3 \mathrm{~min}^{-1}$ with $20 \%$ USY/Al $\mathrm{O}_{3}$ without metallic active phase.

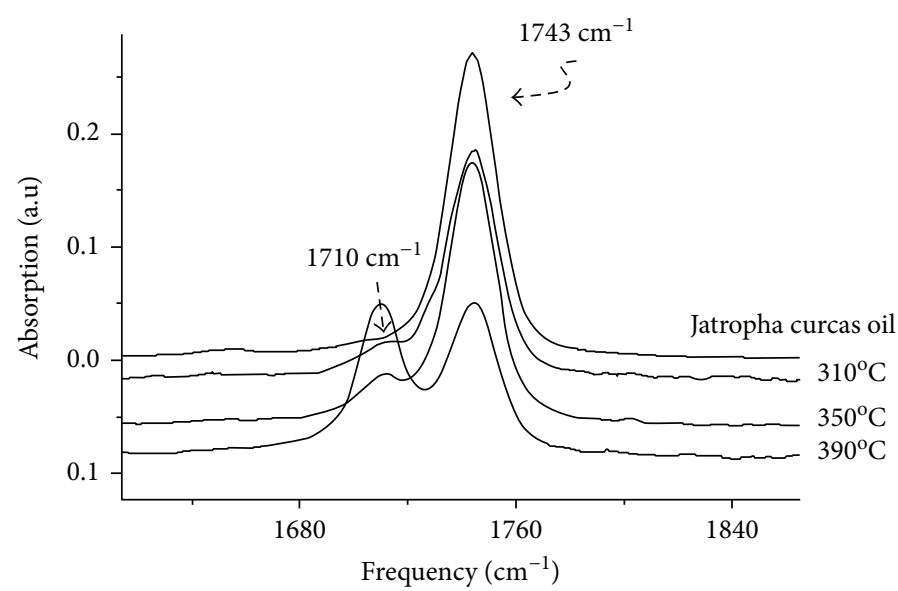

FIGURE 4: Displacement of absorption bands in hydrotreated samples with 20\% USY catalyst with WHSV of $35.28 \mathrm{~h}^{-1}$.

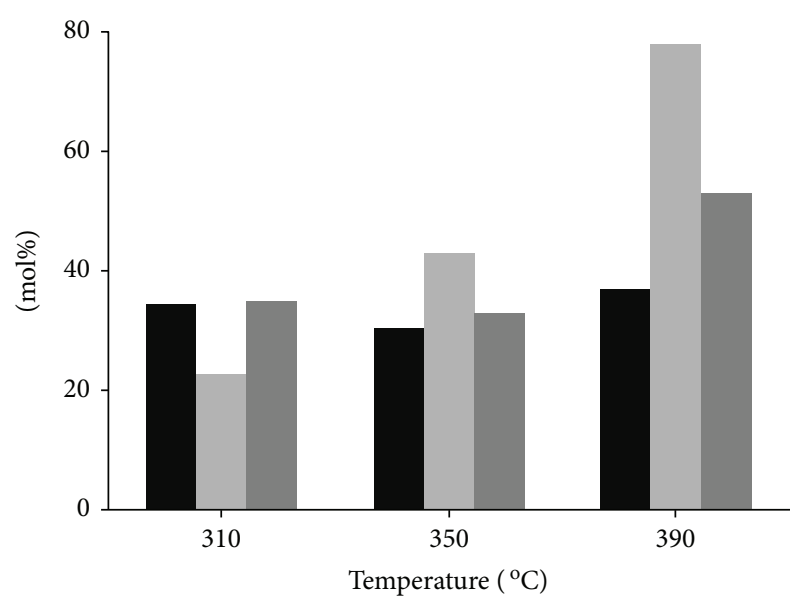

FIgURE 5: Comparative catalytic activity in samples hydrotreated by FTIR at different temperatures and WHSV with platinum-loaded $20 \%$ USY $/ \mathrm{Al}_{2} \mathrm{O}_{3}$ catalyst. (black square) $0.01 \% \mathrm{Pt}$ WHSV = $176.4 \mathrm{~h}^{-1}$; (light gray square) $0.01 \% \mathrm{Pt} \mathrm{WHSV}=35.28 \mathrm{~h}^{-1}$; and (dark gray square) $0.05 \% \mathrm{Pt}$ WHSV $=35.28 \mathrm{~h}^{-1}$.

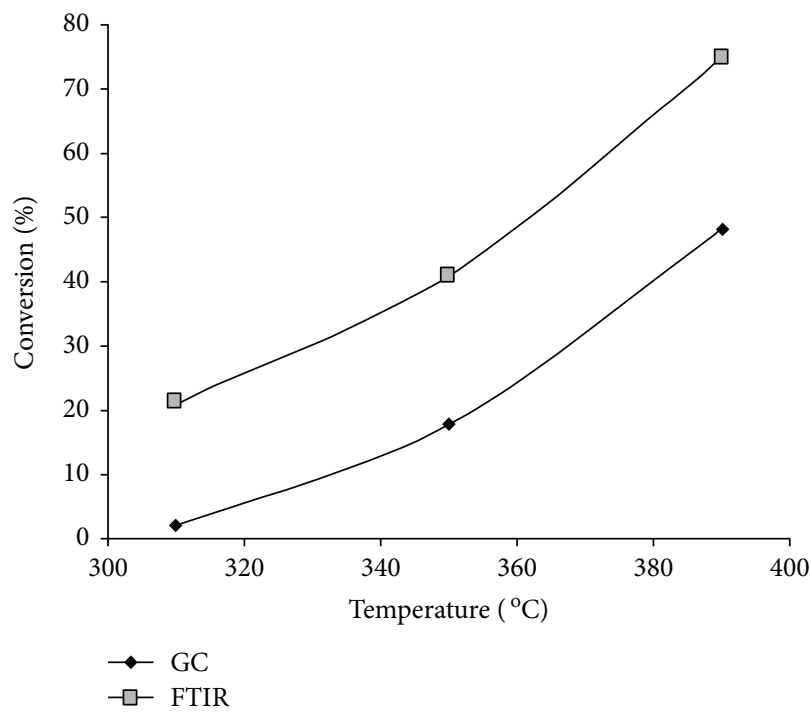

FIgURE 6: Comparative maximum conversion and hydrotreated samples by FTIR and CG/MSD at different temperatures with catalyst $0.01 \% \mathrm{Pt}$ and $20 \% \mathrm{USY} / \mathrm{Al}_{2} \mathrm{O}_{3}$ at $\mathrm{WHSV}=35.28 \mathrm{~h}^{-1}$. 


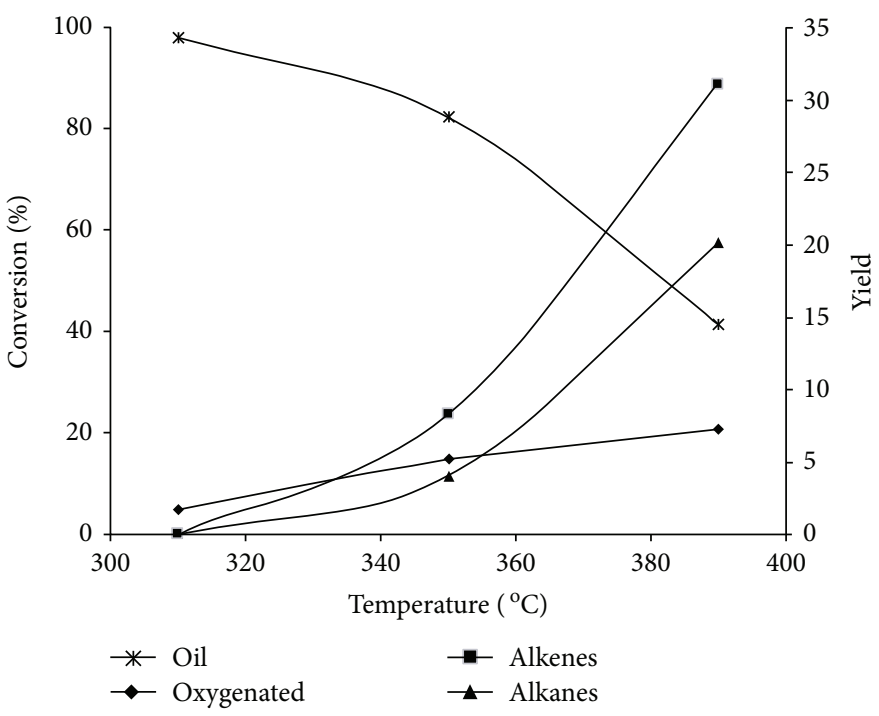

FIGURE 7: Catalytic activity for Jatropha curcas L. seed oil. Catalytic selectivity in functional groups for bifunctional catalyst $0.01 \%$ Pt and $20 \%$ $\mathrm{USY} / \mathrm{Al}_{2} \mathrm{O}_{3}$ at $\mathrm{WHSV}=35.28 \mathrm{~h}^{-1}$.

does not allow the transition towards the acid phase, which results in a rapid saturation of the free fatty acids not allowing molecular cracking reactions [26]. The total triglyceride conversion is proportionality to temperature. At $310^{\circ} \mathrm{C}$, conversion levels reach $20 \%$ with $0.01 \% \mathrm{Pt}$ loaded; at $350^{\circ} \mathrm{C}$, conversion levels increase until $40 \%$; and finally at $390^{\circ} \mathrm{C}$, conversion levels increase to $75 \%$ at WHSV $35.3 \mathrm{~h}^{-1}$.

3.2. CG/MSD. A comparative study of the degree of reaction progression by FTIR and CG/MSD was carried out, where it was observed (Figure 6) that there is a higher degree of advancement by FTIR compared to CG/MSD for the same samples; with increasing temperature at $390^{\circ} \mathrm{C}$, there is a significant difference between the yields for the same catalyst formulation.

Despite this, both analytical techniques coincide in the formulation of the catalyst with $20 \%$ of zeolite USY $/ \mathrm{Al}_{2} \mathrm{O}_{3}$ with a percentage of $0.01 \% \mathrm{Pt}$ as the formulation of greater activity in the hydrotreatment process. The discrepancies in absorbance values obtained by FTIR are overestimated by the presence of compounds with similar $\mathrm{C}=\mathrm{O}$ binding. This is attributed to the formation of light fatty acids of lower molecular weight compared to the initials present in the triglyceride. It is known that in the process, hydrotreating occurs first before hydrocracking [27]. Whereby at a temperature of $310^{\circ} \mathrm{C}$, there is more hydrogenation/dehydrogenating activity than acidic activity [28].

By FTIR analysis, the light fatty acids considered them as reactive for keeping the $\mathrm{C}=\mathrm{O}$ bond current, while for CG/MSD, they were considered as reaction intermediates since they are not part of the initial triglyceride. This difference is observable for each operating temperature performed in this work, where there is the presence of other functional groups that makes the reaction follow-up similar by both techniques.

The formation of partially deoxygenated groups increases as temperature and WHSV increase; these compounds are considered as primary intermediates of reaction of the free fatty acids to olefins and as by-products of reaction to the alkanes and aromatics as a result of processes of cyclization and hydrogenation of the olefins [29]. The hydrocarbon cuts formed have a high selectivity towards the formation of chains of the order of diesel and in less amount hydrocarbon formation of the order of jet fuel and gasolines in a proportion of $6: 1$ and $21: 1$, respectively, Figures 6, 7, and 8 .

It is clearly observed that at a temperature of $390^{\circ} \mathrm{C}$, there is a higher formation of hydrocarbons of the order of diesel with a yield of more than $35 \%$, while for jet fuel and gasolines are maintained at yields of less than $10 \%$; this emphasizes that the catalyst is selective to cuts of diesel. Similar results have been reported by Zheng et al. [16] and Li et al. [15] who reported similar conversions of $68.6 \%$ and $58.7 \%$ of liquid products, respectively, at higher WHSV and temperature values compared with those used in this research.

\section{Conclusions}

The bifunctional catalyst synthesized showed high activity in the hydrotreatment of Jatropha curcas seed oil with a selectivity towards linear hydrocarbon chains; the activity increases as a function of temperature and space velocity but with a decrease in the selectivity towards hydrocarbon chains of the order of the diesel.

The selectivity towards the formation of saturated fatty acids was increased with platinum loading percentages of $0.01 \mathrm{wt} \%$ on the surface of the catalyst responsible for the hydrogenating activity, resulting in a decrease in acid activity. The formulation of the catalyst that showed the highest activity in high molecular weight hydrocarbon cuts is $(0.01 \%) \mathrm{Pt}$ and $(20 \%) \mathrm{USY} / \mathrm{Al}_{2} \mathrm{O}_{3}$ for both process monitoring techniques.

USY zeolite is very active and selective as hydrotreated catalyst, even at moderate conditions, and that can be 

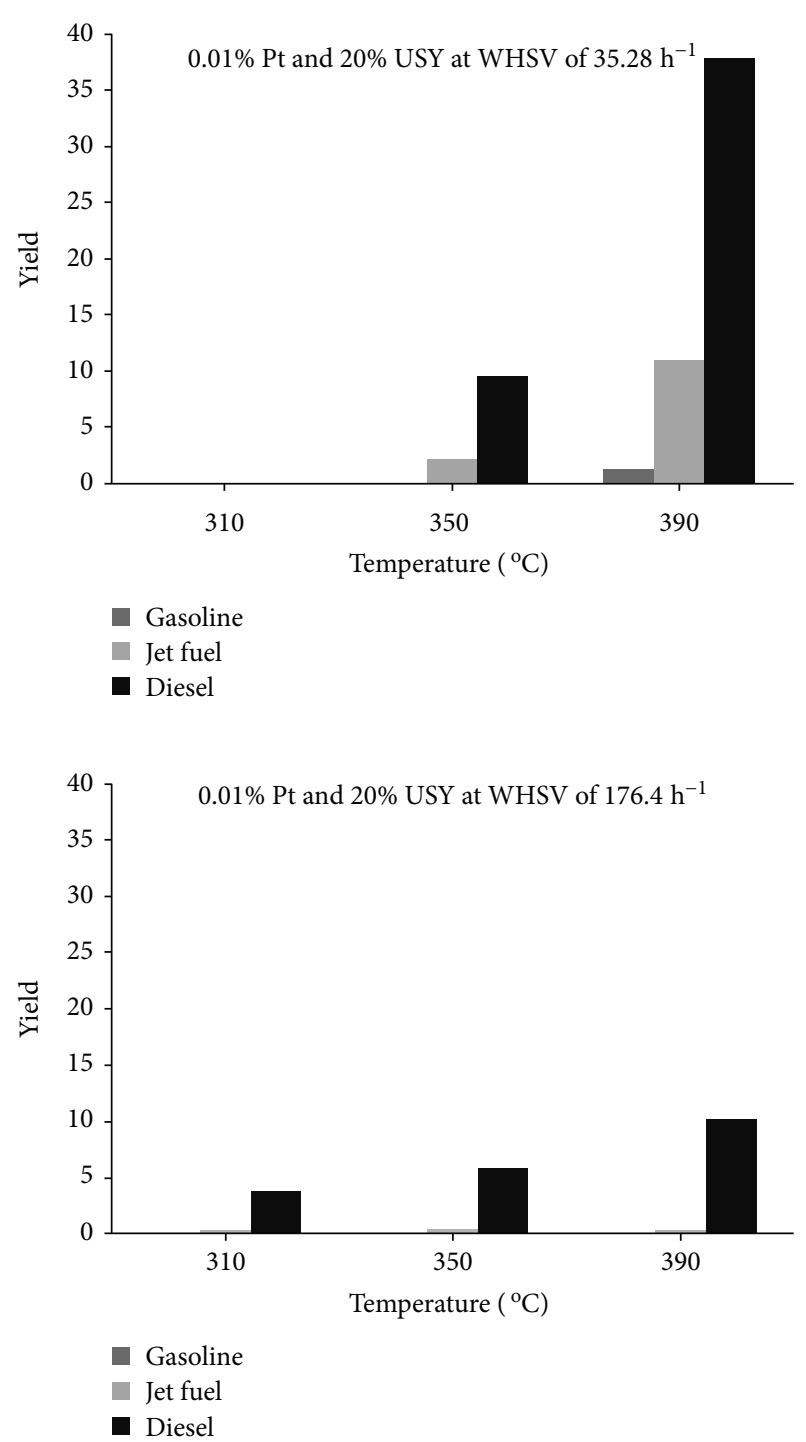

Figure 8: Yield in hydrocarbon cuts as a function of temperature and WHSV with bifunctional catalyst $0.01 \% \mathrm{Pt}$ and $20 \% \mathrm{USY} / \mathrm{Al}_{2} \mathrm{O}_{3}$.

attributed to its acidity function, which is strong enough to accelerate this reaction. Pt incorporation in the zeolite is greatly effective for enhancing the transformation of Jatropha curcas seed oil and for improving the selectivity to the linear hydrocarbons reaction.

\section{Conflicts of Interest}

The authors declare no conflicts of interest.

\section{Acknowledgments}

The authors acknowledge the Consejo Nacional de Ciencia y Tecnología (CONACYT) and Instituto Politécnico Nacional (IPN) for the scholarships during the course of this investigation and the IPN for the financial support for the research.

\section{References}

[1] K. Becker and H. P. S. Makkar, "Jatropha curcas: a potential source for tomorrow's oil and biodiesel," Lipid Technology, vol. 20, no. 5, pp. 104-107, 2008.

[2] J. Hancsók, S. Magyar, and D. Kalló, "Selective hydrodesulphurization of full range FCC gasoline on PtPd/USY-zeolite," Petroleum \& Coal, vol. 46, no. 2, pp. 1-12, 2004.

[3] A. Galadima, J. A. Anderson, and R. P. K. Wells, "Solid acid catalysts in heterogeneous n-alkanes hydroisomerisation for increasing octane number of gasoline," Science World Journal, vol. 4, no. 3, 2010.

[4] M. Chareonpanich, Z.-G. Zhang, and A. Tomita, "Hydrocracking of aromatic hydrocarbons over USY-zeolite," Energy \& Fuels, vol. 10, no. 4, pp. 927-931, 1996.

[5] Y. Y. A. Pertuz, L. A. Oviedo, U. U. Navarro, M. A. Centeno, and J. A. Odriozola, "Modificaciones de las propiedades texturales y estructurales de una zeolita USY y de sus mezclas con caolín clay y clorhidrol como consecuencia del tratamiento hidrotérmico," Revista Colombiana de Química, vol. 35, no. 1, 2006.

[6] A. M. Alsobaai, R. Zakaria, and B. H. Hameed, "Hydrocracking of gas oil over Ni-W, Ni-Mo, Co-W and Co-Mo catalysts supported on USY zeolite," Arab Research Institute in Sciences \& Engineering, vol. 3, no. 3, pp. 91-98, 2007.

[7] A. M. Alsobaai, R. Zakaria, and B. H. Hameed, "Characterization and hydrocracking of gas oil on sulfided NiW/MCM-48 catalysts," Chemical Engineering Journal, vol. 132, no. 1-3, pp. 173-181, 2007.

[8] T. Morgan, D. Grubb, E. Santillan-Jimenez, and M. Crocker, "Conversion of triglycerides to hydrocarbons over supported metal catalysts," Topics in Catalysis, vol. 53, no. 11-12, pp. 820-829, 2010.

[9] Y. Liu, R. Sotelo-Boyás, K. Murata, T. Minowa, and K. Sakanishi, "Hydrotreatment of vegetable oils to produce bio-hydrogenated diesel and liquefied petroleum gas fuel over catalysts containing sulfided Ni-Mo and solid acids," Energy \& Fuels, vol. 25, no. 10, pp. 4675-4685, 2011.

[10] S. Bezergianni and A. Kalogianni, "Hydrocracking of used cooking oil for biofuels production," Bioresource Technology, vol. 100, no. 17, pp. 3927-3932, 2009.

[11] N. Taufiqurrahmi, A. R. Mohamed, and S. Bhatia, "Deactivation and coke combustion studies of nanocrystalline zeolite beta in catalytic cracking of used palm oil," Chemical Engineering Journal, vol. 163, no. 3, pp. 413-421, 2010.

[12] J. García-Dávila, E. Ocaranza-Sánchez, M. Rojas-López, J. A. Muñoz-Arroyo, J. Ramírez, and A. L. Martínez-Ayala, "Jatropha curcas L. oil hydroconversion over hydrodesulfurization catalysts for biofuel production," Fuel, vol. 135, pp. 380-386, 2014.

[13] A. L. F. Santos, D. U. Martins, O. K. Iha, R. A. M. Ribeiro, R. L. Quirino, and P. A. Z. Suarez, "Agro-industrial residues as lowprice feedstock for diesel-like fuel production by thermal cracking," Bioresource Technology, vol. 101, no. 15, pp. 61576162, 2010.

[14] M. Díaz de León-Cabrera and M. A. Sánchez-Castillo, "Basis for triglycerides and phospholipids conversion into fuels using mesoporous catalysts," Revista Mexicana de Ingeniería Química, vol. 15, no. 1, pp. 111-128, 2016.

[15] L. Li, Z. Ding, K. Li et al., "Liquid hydrocarbon fuels from catalytic cracking of waste cooking oils using ultrastable zeolite 
USY as catalyst," Journal of Analytical and Applied Pyrolysis, vol. 117, pp. 268-272, 2016.

[16] Q. Zheng, L. Huo, H. Li et al., "Exploring structural features of USY zeolite in the catalytic cracking of Jatropha curcas L. seed oil towards higher gasoline/diesel yield and lower $\mathrm{CO}_{2}$ emission," Fuel, vol. 202, pp. 563-571, 2017.

[17] K. Murata, Y. Liu, M. Inaba, and I. Takahara, "Production of synthetic diesel by hydrotreatment of jatropha oils using PtRe/H-ZSM-5 catalyst," Energy \& Fuels, vol. 24, no. 4, pp. 2404-2409, 2010.

[18] B. Lombardi, M. A. Dapino, P. R. Montardit, and R. M. Torres Sánchez, "Aproximación al valor de superficie específica por un método manual y simple," Jornadas SAM-CONAMETAAS, vol. 1, pp. 251-256, 2011.

[19] D. Bazin, D. Guillaume, C. Pichón, D. Uzio, and S. Lopez, "Structure and size of bimetallic palladium-platinum clusters in an hydrotreatment," Oil \& Gas Science and Technology, vol. 60, no. 5, pp. 801-813, 2005.

[20] J. García-Dávila, E. Ocaranza-Sánchez, C. Sánchez, E. OrtegaSánchez, S. Tlecuitl-Beristaín, and A. L. Martínez-Ayala, "FTIR analysis of hydrotreated Jatropha curcas L. seed oil over Ni-Mo catalyst for biofuel production," Revista Mexicana de Ingeniería Química, vol. 16, no. 2, pp. 337-345, 2017.

[21] J. K. Satyarthi and D. Srinivas, "Fourier transform infrared spectroscopic method for monitoring hydroprocessing of vegetable oils to produce hydrocarbon-based biofuel," Energy \& Fuels, vol. 25, no. 7, pp. 3318-3322, 2011.

[22] R. O. Idem, S. P. R. Katikaneni, and N. N. Bakhshi, "Catalytic conversion of canola oil to fuels and chemicals: roles of catalyst acidity, basicity and shape selectivity on product distribution," Fuel Processing Technology, vol. 51, no. 1-2, pp. 101-125, 1997.

[23] M. Chiappero, P. T. M. Do, S. Crossley, L. L. Lobban, and D. E. Resasco, "Direct conversion of triglycerides to olefins and paraffins over noble metal supported catalysts," Fuel, vol. 90, no. 3, pp. 1155-1165, 2011.

[24] D. Kubicka, P. Símácék, and N. Zilkova, "Transformation of vegetable oils into hydrocarbons over mesoporous-aluminasupported CoMo catalysts," Topics in Catalysis, vol. 52, no. 1-2, pp. 161-168, 2009.

[25] G. W. Huber, P. O’Connor, and A. Corma, "Processing biomass in conventional oil refineries: production of high quality diesel by hydrotreating vegetable oils in heavy vacuum oil mixtures," Applied Catalysis A: General, vol. 329, pp. 120-129, 2007.

[26] S. A. El-Khatib, M. G. Abd El-Wahed, L. K. Mohamed, and S. A. El-Saadany, "Hydroconversion of n-octane over platinum containing H-ZSM-5 zeolite and alumina catalysts," Journal of Applied Sciences Research, vol. 5, no. 9, pp. 1163-1172, 2009.

[27] S. Bezergianni, A. Kalogianni, and I. A. Vasalos, "Hydrocracking of vacuum gas oil-vegetable oil mixtures for biofuels production," Bioresource Technology, vol. 100, no. 12, pp. 3036-3042, 2009.

[28] J. Hancsók, S. Magyar, K. Juhász, and D. Kalló, "HDS, HDN and HDO of FCC gasoline spiked with benzothiophene over PtPd/H-USY," Topics in Catalysis, vol. 45, no. 1-4, pp. 207212, 2007.

[29] E. Vonghia, D. G. B. Boocock, S. K. Konar, and A. Leung, "Pathways for the deoxygenation of triglycerides to aliphatic hydrocarbons over activated alumina," Energy \& Fuels, vol. 9, no. 6, pp. 1090-1096, 1995. 

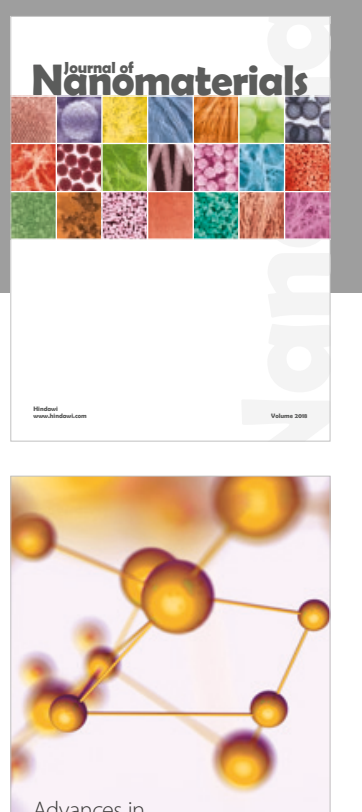

Physical Chemistry
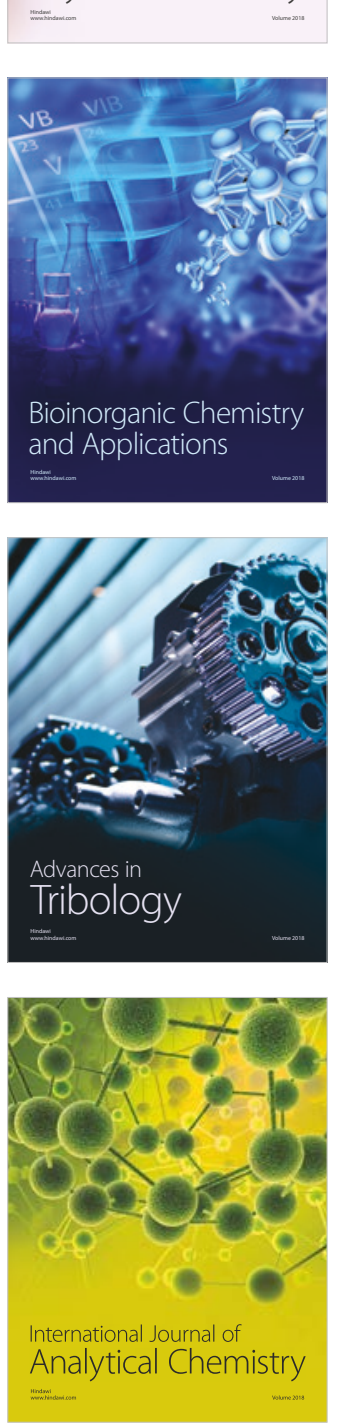

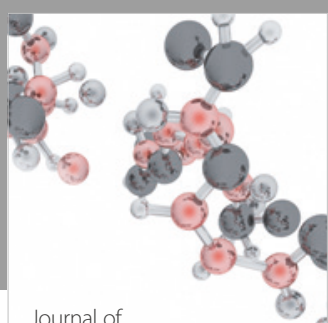

Analytical Methods

in Chemistry

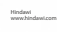

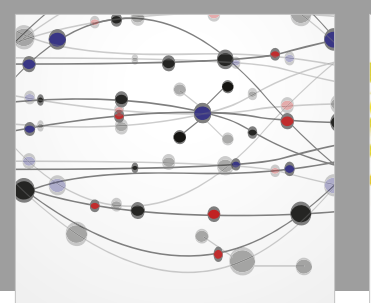

The Scientific World Journal

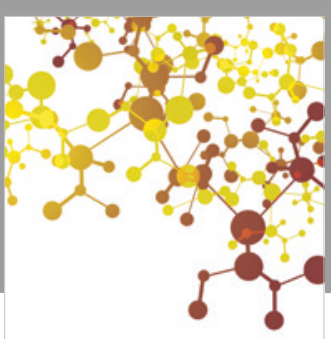

Journal of

Applied Chemistry
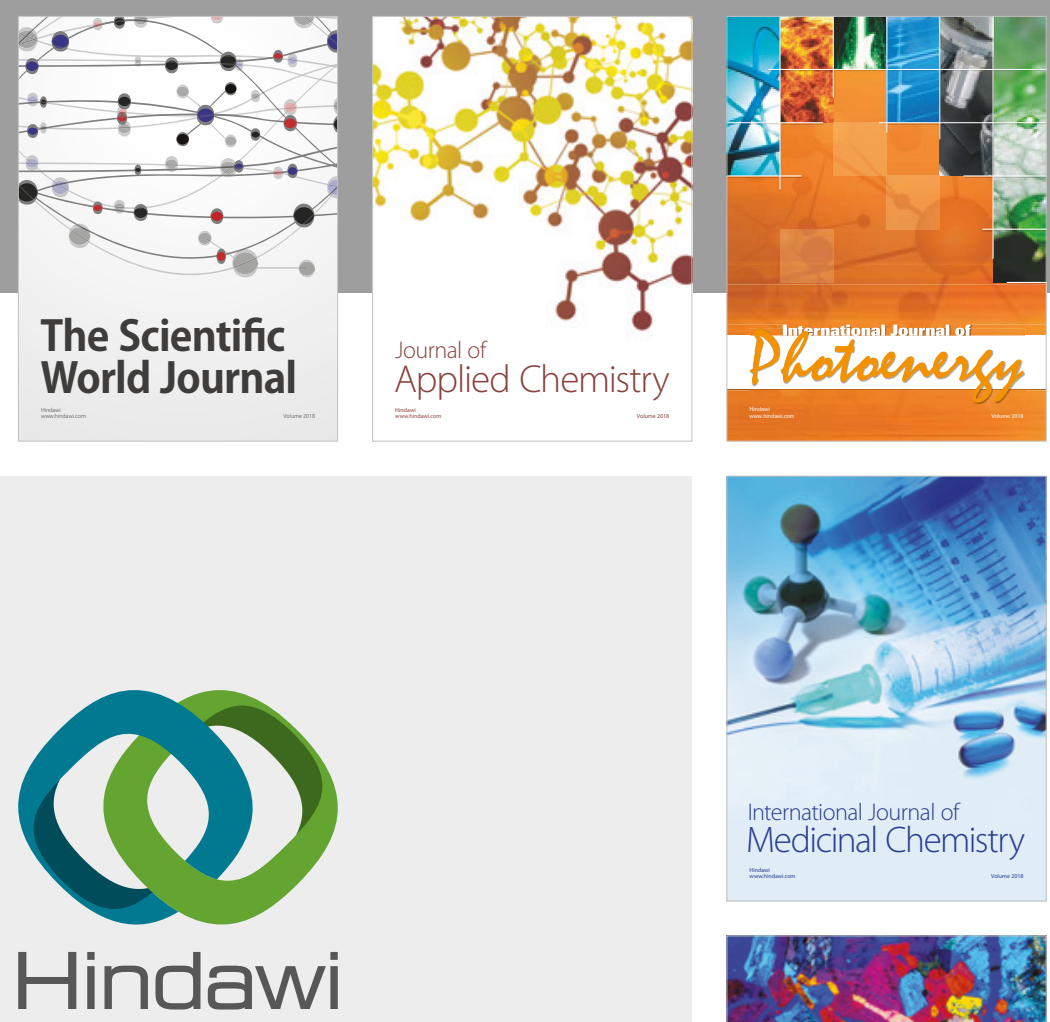

Submit your manuscripts at

www.hindawi.com
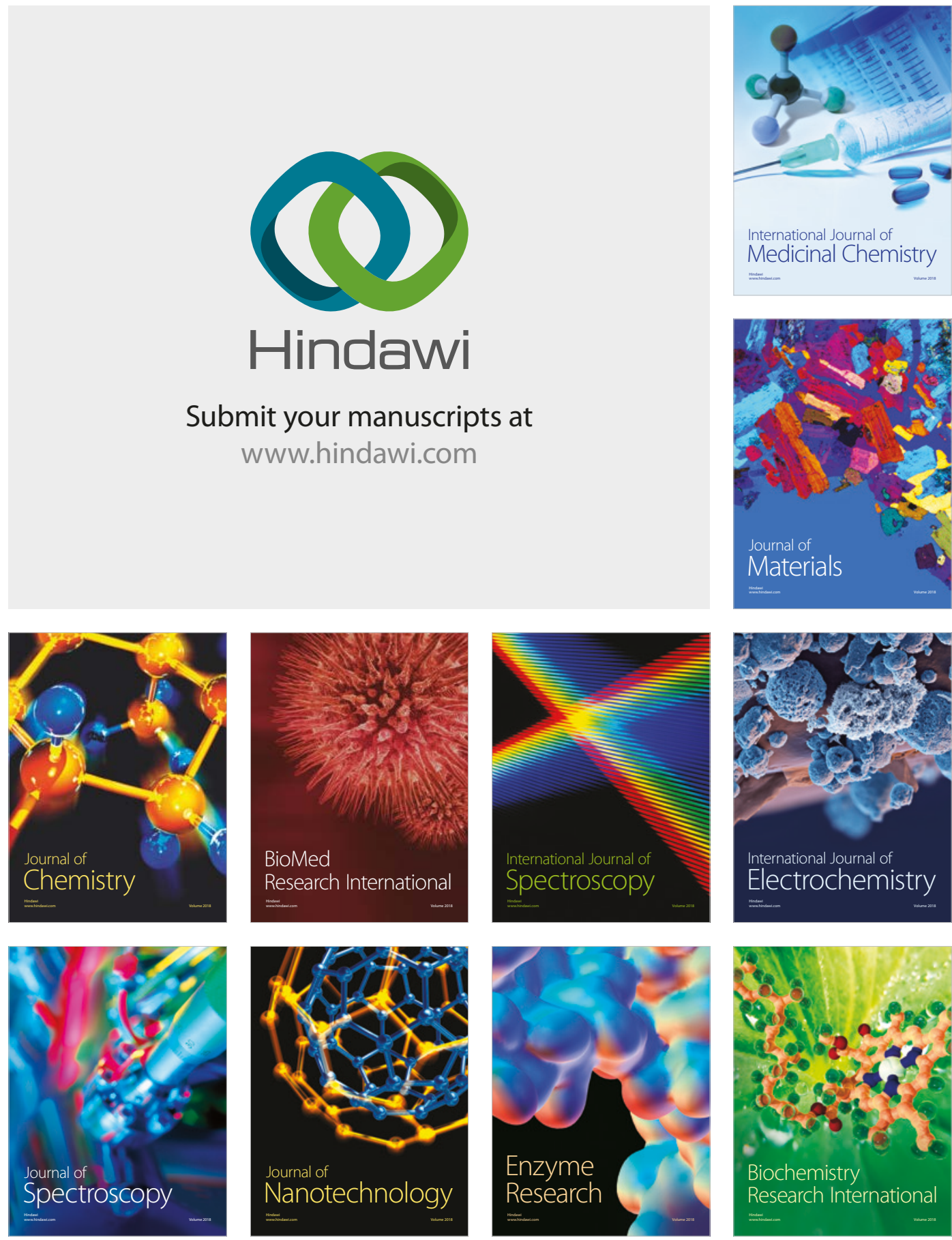
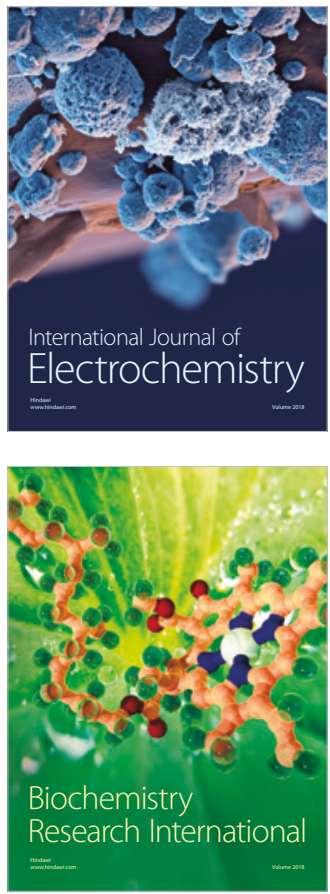